\title{
Analgesic, Anti-diarrheal, Anti-depressant, Membrane Stabilizing and Cytotoxic Activities of Bridelia verrucosa Haines
}

\author{
Tasmia Tabassum ${ }^{1}$, Md. Abdul Bari ${ }^{1}$, Md. Ruhul Kuddus ${ }^{2}$ and \\ Mohammad A. Rashid ${ }^{2}$ \\ ${ }^{1}$ Department of Pharmacy, State University of Bangladesh, Dhaka-1205, Bangladesh \\ ${ }^{2}$ Department of Pharmaceutical Chemistry, Faculty of Pharmacy, University of Dhaka \\ Dhaka-1000, Bangladesh
}

(Received: July 5, 2018; Accepted: October 25, 2018; Published: January 17, 2019)

\begin{abstract}
The present study was aimed for the evaluation of analgesic, anti-diarrheal and anti-depressant activities of methanol crude extract of Bridelia verrucosa leaves in Swiss albino mice. The analgesic activity was assessed by formalin-induced paw licking method, where the crude extract of B. verrucosa (400 mg/kg, b.w.) exhibited $54.55 \%$ reduction of licking response in mice as compared to $69.09 \%$ reduction exhibited by standard acetylsalicylic acid. In the castor oil-induced diarrhea in mice, the plant extract at the dose of $400 \mathrm{mg} / \mathrm{kg}$, b.w., demonstrated $57.67 \%$ reduction of diarrheal feces in mice. The antidepressant activity of the plant extract was evaluated through phenobarbitone-Na induced sleeping time test. The methanol extract of B. verrucosa and its different Kupchan fractions were also subjected to screenings for membrane stabilizing and cytotoxic activities using acetylsalicylic acid and vincristine sulphate as standard, respectively.
\end{abstract}

Key words: Bridelia verrucosa, analgesic, anti-diarrheal, anti-depressant, membrane stabilizing, cytotoxic.

\section{Introduction}

Plant-based medicines have been used in traditional health care system since the ancient civilization. According to World Health Organization (WHO), $80 \%$ of the population, mostly in developing countries still relies on plant-based medicines for their primary health care (Ghani, 2003; Ezuruike and Prieto, 2014; Samsam and Moatar, 1991). Plants and microbes produce a diverse range of bioactive molecules, making them a rich source of different types of medicines (Cragg and Newman, 2013; Rashid et al., 2014). In modern medicines, they occupy a very significant place as raw materials for important therapeutic agents (Dias et al., 2012). Natural bioactive compounds obtained from different parts of the plants like roots, leaves, stem, bark, fruits and seeds have shown the promising results in the treatment of various diseases and improving human life (Yuan et al., 2016; Salehi et al., 2018). Therefore, the presence of various life sustaining constituents in plants has always encouraged natural product chemists to carry out investigations for finding new therapeutic agents for the various fields of biomedicine.

Bridelia verrucosa Haines (Local name: Ghiyai; Family: Phyllanthaceae) is a large shrub or straggling tree without thrones. The plant is $2.5-5 \mathrm{~m}$ tall, which is widely distributed in Chittagong hill tracts, Bangladesh (Kirtikar and Basu, 1980; Gricson and Long, 1987). The plant has been extensively known for its anthelmintic property. The root and the bark of the plant are frequently used as astringent in Mumbai and Goa in India (Caicus, 1998; Singh and Ali, 1998). Previous phytochemical studies with this plant

Correspondence to: Mohammad A. Rashid; Tel.: +88-02-9661900-73, Extn. 8137; Fax: +88-02-9667222; E-mail: r.pchem@yahoo.com 
led to the isolation of glochidonol, brassicasterol, friedelin, ketooleanane, pinoresinol, stigmasterol, sitosterol, its glucoside and hexacosanol, etc (Singh and Ali, 1998; Anjum et al., 2017).

As part of our ongoing efforts to study Bridelia species (Anjum et al., 2017; Anjum et al., 2013) we evaluated the analgesic, anti-diarrheal, antidepressant, membrane stabilizing and cytotoxic activities of $B$. verrucosa as well as to justify the rationale behind its folk uses.

\section{Materials and Methods}

Plant material: Leaves of Bridelia verrucosa were collected from Botanical Garden, Dhaka, Bangladesh, in July 2017 and identified in Bangladesh National Herbarium, Mirpur, Dhaka where a voucher specimen has been deposited.

The plant sample was air-dried and ground to a coarse powder using a grinding machine. The powdered material (425 g) of B. verrucosa was macerated in 2.51 of methanol for 15 days and finally, filtered through Whatman filter paper number 1. The filtrate was concentrated using rotary evaporator at $40^{\circ} \mathrm{C}$ under reduced pressure. About $5 \mathrm{~g}$ of the concentrated extract of B. verrucosa was subjected to solvent-solvent partitioning following the modified Kupchan method (VanWagenen et al., 1993) to yield petroleum-ether, dichloromethane, chloroform and aqueous soluble fractions. Then the crude extract and its Kupchan fractions were separately evaluated for biological activities.

Drugs and reagents: Methanol, formalin, Tween-80, loperamide (Square Pharmaceuticals Ltd.), normal saline (Opsonin Pharmaceuticals Ltd.), morphine and phenobarbitone-Na, (Gonoshasthaya Pharmaceuticals Ltd.), acetylsalicylic acid (Essential Drugs Company Ltd.) and castor oil were collected from local market. All other chemicals and solvents were of analytical grade.

Experimental animal: Swiss Albino mice (28-30 g) of either sex aged 4-5 weeks were collected from the Animal Resource Branch of the International Centre for Diarrheal Diseases and Research, Bangladesh (icddr,b). The mice were housed in standard polypropylene cages and kept at room temperature $\left(24 \pm 2^{\circ} \mathrm{C}\right)$ and relative humidity $(60$ -

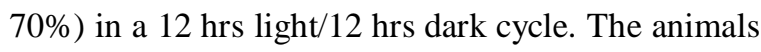
were fed with icddr,b formulated diet and water $a d$ libitum.

Analgesic activity: The analgesic activity of $B$. verrucosa extract was determined by formalininduced paw licking method in mice (Barua et al., 2011). In this method, the test groups received the plant extract at $200-$ and $400-\mathrm{mg} / \mathrm{kg}$ b.w., while the positive control- and negative control-mice were treated orally with standard drug acetylsalicylic acid (50 mg/kg, p.o.) and $1 \%$ Tween-80 in normal saline, respectively. About $30 \mathrm{~min}$ after treatment, 1\% formalin $(0.1 \mathrm{ml} / 10 \quad \mathrm{~g}, \quad$ b.w. $)$ was injected subcutaneously under dorsal surface of the hind paw and the time spent for licking the injected paw with formalin was counted for $5 \mathrm{~min}$ post formalin injection and considered as indications of the pain stimuli. The percent (\%) inhibition of licking response in comparison to control group was taken as an index of analgesia and was calculated using the following formula

$$
\% \text { Inhibition }=\left(\mathrm{L}_{\mathrm{C}}-\mathrm{L}_{\mathrm{T}}\right) / \mathrm{L}_{\mathrm{C}} \times 100 \%
$$

where $\mathrm{L}_{\mathrm{C}}=$ Licking response by control and $\mathrm{L}_{\mathrm{T}}=$ Licking response by test groups.

Anti-diarrheal activity: Anti-diarrheal activity of the crude methanolic extract of $B$. verrucosa was determined following the published method (Shoba and Thomas, 2001) with slight modification. The negative control group received vehicle (1\% Tween80 in normal saline) at $10 \mathrm{ml} / \mathrm{kg} \mathrm{b.w.} \mathrm{orally,} \mathrm{while} \mathrm{the}$ positive control group received loperamide (50 $\mathrm{mg} / \mathrm{kg}$ b.w.) orally. The test group received the extract of B. verrucosa at 200- and 400- $\mathrm{mg} / \mathrm{kg}$ b.w. orally. After $30 \mathrm{~min}$ intervals to ensure proper absorption of the administered substance, $1.0 \mathrm{ml}$ of castor oil was fed to each mouse to induce diarrhea. Each animal was placed in an individual case, the floor of which was lined with blotting paper. Each of the mice was observed for $4 \mathrm{~h}$ to record the number of stool giving instances. The average of total number of stool given by the test group, and the control group was compared and the percent inhibition of 
defecation in mice was calculated by using the following equation

$\%$ Inhibition $=\left(\mathrm{M}_{\mathrm{C}}-\mathrm{M}_{\mathrm{T}}\right) / \mathrm{M}_{\mathrm{C}} \times 100$

Where, $\mathrm{M}_{\mathrm{C}}=$ Mean defecation of control and $\mathrm{M}_{\mathrm{T}}$ $=$ Mean defecation of test groups.

Anti-depressant assay: The crude methanolic extract of $B$. verrucosa was subjected for the evaluation of antidepressant assay through phenobarbitone-Na induced sleeping time test (Rahman et al., 2015). Here, the test groups were orally administered with test samples prepared with normal saline water and Tween-80 at doses of 200and $400-\mathrm{mg} / \mathrm{kg}$ b.w., while the positive control group was treated with diazepam $(1 \mathrm{mg} / \mathrm{kg}$ b.w.) and the negative control group with normal saline water containing $1 \%$ Tween-80. 30 min later, phenobarbitone-Na (40 $\mathrm{mg} / \mathrm{kg} \quad$ b.w.) was administered intraperitoneally to each mouse to induce sleep. The animals were observed for the latent period for time of onset of sleep (i.e. time between phenobarbitone- $\mathrm{Na}$ and loss of righting reflex) and duration of sleep (i.e. time between the loss and recovery of righting reflex).

Membrane stabilizing activity: The membrane stabilizing activity of the crude extract of $B$. verrucosa and its Kupchan partitionates were subjected to assay for membrane stabilizing activity following the method (Shinde et al., 1999) of hypotonic-and heat-induced hemolysis of human erythrocyte using acetylsalicylic acid as standard.

Cytotoxic activity: To determine the cytotoxic activity, the plant extractives dissolved in dimethyl sulfoxide (DMSO) were applied against Artemia salina in a one-day ex-vivo assay using vincristine sulphate and DMSO as the positive and negative control, respectively (Rashid et al., 2016).

\section{Results and Discussion}

The present study was undertaken to evaluate the analgesic, anti-diarrheal, anti-depressant, membrane stabilization and cytotoxic activities of the organic soluble materials of a methanol extract of $B$. verrucosa and the results have been summarized in tables 1-4.

The analgesic activity of $B$. verrucosa extract (Table 1) was determined by formalin-induced paw licking method in mice. The formalin test has been described as a convenient method for producing and quantifying pain in rats (Dubuisson and Dennis, 1977). The test employs a painful stimulus to which the animals show a spontaneous response and it is sensitive to commonly used analgesics. Subcutaneous injection of $1 \%$ formalin evoked a characteristic licking response in the Albino mice.

Table 1. Analgesic activity of methanol extract of $B$. verrucosa in Swiss Albino mice.

\begin{tabular}{lcc}
\hline Test groups & $\begin{array}{c}\text { Average time } \\
\text { (s.) of licking } \\
\text { response }\end{array}$ & $\begin{array}{c}\text { \% Inhibition of } \\
\text { licking } \\
\text { response }\end{array}$ \\
\hline $\begin{array}{l}\text { Control } \\
\text { ASA }\end{array}$ & 18.33 & -- \\
$(50 \mathrm{mg} / \mathrm{kg}$ b.w. $)$ & 5.67 & 69.09 \\
$\mathrm{MEBV}$ & 9.33 & 49.09 \\
$(200 \mathrm{mg} / \mathrm{kg}$ b.w. $)$ & & \\
$\mathrm{MEBV}$ & 8.33 & 54.55 \\
$(400 \mathrm{mg} / \mathrm{kg}$ b.w. $)$ & & \\
\hline
\end{tabular}

Here, MEBV = Methanol extract of $B$. verrucosa, ASA = Acetyl salicylic acid.

In this study, the plant extract revealed a dosedependent decrease in licking time and licking frequency by the mice injected with formalin signifying the analgesic effect of the extract. Although the active doses of the plant extract were higher than those of the reference drug, it should be noted that the crude extract is made up of different compositions of many substances.

In the castor oil-induced diarrhea, the crude methanol extract of $B$. verrucosa produced marked anti-diarrheal effect in the mice, as shown in table 2. Here, the plant extract at the dose of 200- and 400$\mathrm{mg} / \mathrm{kg}$ b.w. demonstrated reduction of diarrheal feces by $46.15 \%$ and $57.67 \%$, respectively when compared with loperamide which reduced the same by $61.59 \%$. In the evaluation of anti-diarrheal activity, the crude extract showed statistically significant activity. 
Table 2. Antidiarrheal activity of methanol extract of $B$. verrucosa in Swiss Albino mice.

\begin{tabular}{lcc}
\hline Test groups & $\begin{array}{c}\text { No. of diarrheal } \\
\text { feces }\end{array}$ & $\begin{array}{c}\text { \% Reduction of } \\
\text { diarrheal feces }\end{array}$ \\
\hline $\begin{array}{l}\text { Control } \\
\text { Loperamide }\end{array}$ & 8.67 & -- \\
$(50 \mathrm{mg} / \mathrm{kg} \mathrm{b.w.)}$ & 3.33 & 61.59 \\
$\begin{array}{l}\text { MEBV } \\
(200 \mathrm{mg} / \mathrm{kg} \text { b.w. })\end{array}$ & 4.67 & 46.15 \\
$\begin{array}{l}\text { MEBV } \\
(400 \mathrm{mg} / \mathrm{kg} \text { b.w. })\end{array}$ & 3.67 & 57.67 \\
\hline
\end{tabular}

In addition, the plant extract considerably shortened the time for onset of sleep and prolonged the duration of phenobarbitone-induced sleep in mice (Table 3). This anti-depressant activity was comparable to the reference drug diazepam.

Table 3. Anti-depressant activity of crude extract of $B$. verrucosa in Swiss Albino mice.

\begin{tabular}{lcc}
\hline Test groups & $\begin{array}{c}\text { Time of } \\
\text { onset of } \\
\text { sleep (min.) }\end{array}$ & $\begin{array}{c}\text { Total } \\
\text { sleeping time } \\
\text { (min.) }\end{array}$ \\
\hline Control & 47.06 & 116.67 \\
Phenobarbitone & 16.33 & 288.33 \\
$(50 \mathrm{mg} / \mathrm{kg}$ b.w.) & & \\
MEBV & 22.24 & 221.72 \\
$(200 \mathrm{mg} / \mathrm{kg}$ b.w. $)$ & & \\
$\begin{array}{l}\text { MEBV } \\
(400 \mathrm{mg} / \mathrm{kg} \text { b.w.) }\end{array}$ & 21.67 & 234.0 \\
\hline
\end{tabular}

The extractives of $B$. verrucosa at concentration $2.0 \mathrm{mg} / \mathrm{ml}$, significantly protected the lysis of mice erythrocyte membrane induced by hypotonic solution and heat, as compared to the standard acetyl salicylic acid $(0.10 \mathrm{mg} / \mathrm{ml})$ (Table 4$)$. In hypotonic solutioninduced haemolysis, the aqueous soluble fraction of crude extract of B. verrucosa inhibited $45.56 \%$ haemolysis of RBC, as compared to $47.12 \%$ produced by acetyl salicylic acid. The crude extract of $B$. verrucosa also demonstrated significant inhibition of haemolysis of RBCs. On the other hand, in heat-induced haemolysis, the crude extract inhibited 57.13\% haemolysis of RBC (Table 4).

In the present study, all the plant samples i.e., the crude methanol extract of leaf of $B$. verrucosa and its petroleum-ether, dichloromethane, chloroform and aqueous soluble fractions showed positive results in brine shrimp lethality bioassay which suggested that the test samples are biologically active. Each of the test samples showed different mortality rates at different concentrations. Plotting of $\log$ of concentration versus percent mortality for all test samples showed an approximate linear correlation. From the graphs, the median lethal concentration $\left(\mathrm{LC}_{50}=\right.$ the concentration at which $50 \%$ mortality of brine shrimp nauplii occurred) was determined for the samples.

Table 4. Membrane stabilizing and cytotoxic activities of different extracts of $B$. verrucosa.

\begin{tabular}{lccc}
\hline \multirow{2}{*}{ Sample } & \multicolumn{2}{c}{$\%$ Inhibition of hemolysis } & \multicolumn{2}{c}{ LC $_{50}(\mu \mathrm{g} / \mathrm{ml})$} \\
\cline { 2 - 3 } & $\begin{array}{c}\text { Hypotonic } \\
\text { solution-induced }\end{array}$ & Heat-induced & 10.0 \\
\hline MEBV & 40.2 & 57.13 & 14.7 \\
PESF & 22.81 & 37.13 & 44.3 \\
DCMSF & 32.13 & 27.07 & 2.2 \\
CSF & 18.2 & 16.64 & 16.2 \\
AQSF & 45.56 & 14.72 & 0.582 \\
VS & -- & -- & -- \\
ASA & 47.12 & 42.12 & \\
\hline
\end{tabular}

Here, $\mathrm{PESF}=$ Petroleum-ether soluble fraction, DCMSF $=$ Dichloromethane soluble fraction, $\mathrm{CSF}=$ Chloroform soluble fraction, $\mathrm{AQSF}=$ Aqueous soluble fraction of methanolic extract of B. verrucosa, $\mathrm{VS}=\mathrm{Vincristine}$ sulphate. 
The chloroform soluble fraction of crude methanol extract of $B$. verrucosa leaf demonstrated strong cytotoxic activity with $\mathrm{LC}_{50}$ value of $2.2 \mu \mathrm{g} / \mathrm{ml}$ while the crude methanol extract and its petroleumether and aqueous soluble fractions were also significantly cytotoxic with $\mathrm{LC}_{50}$ values of 10.0, 14.7 and $16.2 \mu \mathrm{g} / \mathrm{ml}$, respectively as compared to 0.582 $\mu \mathrm{g} / \mathrm{ml}$ produced by vincristine sulphate (Table 4 ). The current finding is also supported by previous study (Anjum et al., 2017) where the pure compounds isolated from $B$. verrucosa exhibited cytotoxic activity against brine shrimp nauplii.

\section{Conclusion}

Finally, it can be concluded that the methanol extract of $B$. verrucosa possesses noticeable analgesic, anti-diarrheal, anti-depressant, membrane stabilizing and cytotoxic activities, and there by supports the traditional uses of the Bridelia species in various diseases such as diabetes, infection, diarrhea, malaria etc (Ngueyem et al., 2009). Here, we focused a preliminary screening which will require further detailed investigation to confirm these findings as well as to isolate and characterize the bioactive compounds.

\section{References}

Anjum, A., Sikder, M.A., Haque, M.R., Hasan, C.M. and Rashid, M.A. 2013. In Vitro antioxidant and thrombolytic activities of Bridelia species growing in Bangladesh. J. Sci. Res. 5, 343-351.

Anjum, A., Sultan, M.Z., Hasan, C.M. and Rashid, M.A. 2017. Antibacterial and cytotoxic constituents from Bridelia verrucosa Haines growing in Bangladesh. Dhaka Univ. J. Pharm. Sci. 16, 61-68.

Barua, C.C., Roy, J.D., Buragohain, B., Barua, A.C., Borah, P., and Lahkar, M. 2011. Analgesic and anti-nociceptive activity of hydroethanolic extract of Drymaria cordata Willd. Indian J. Pharmacol. 43, 121-125.

Caicus, J.F. 1998. The Medicinal and Poisonous Plants of India. Scientific Publishers, India; 4th reprint, pp. 273274.
Cragg, G.M. and Newman, D.J. 2013. Natural products: A continuing source of novel drug leads. Biochimica et Biophysica Acta (BBA) 1830, 3670-3695.

Dias, D.A., Urban, S. and Roessner, U. 2012. A historical overview of natural products in drug discovery. Metabolites. 2, 303-336.

Dubuisson, D. and Dennis, S.G. 1977. The formalin test: a quantitative study of the analgesic effects of morphine, meperidine and brain stem stimulation in rats and cats. Pain 4, 161-174.

Ezuruike, U.F. and Prieto, J.M. 2014. The use of plants in the traditional management of diabetes in Nigeria: Pharmacological and toxicological considerations. $J$. Ethnopharmacol. 155, 857-924.

Ghani, A. 2003. Medicinal plants of Bangladesh: Chemical constituents and uses. $2^{\text {nd }}$ edition, Asiatic Society of Bangladesh, Dhaka.

Gricson, A.J.C. and Long, D.G. 1987. Flora of Bhutan. Edn 1, Vol. 3, Royal Botanic Garden, Edinburgh.

Kirtikar, K.R. and Basu, B.D. 1980. Indian Medicinal Plants. Edn 2, Vol. 3, Lalit Mohan Basu, Allahabad, India.

Ngueyem, T.A., Brusotti, G., Caccialanza, G. and Finzi, P.V. 2009. The genus Bridelia: A phytochemical and ethnopharmacological review. J. Ethnopharmacol. 124, 339-349.

Rahman, M.S., Jahan, N. Rahman, S.M.A. and Rashid, M.A. 2015. Analgesic and antidepressant activities of Brassica rapa subspecies chinensis (L.) Hanelt on Swiss Albino mice model. Bangladesh Med. Res. Counc. Bull. 41, 114-120.

Rashid, M.A., Haque, M.R., Sikder, M.A., Chowdhury, A.A., Rahman, M.S. and Hasan, C.M. 2014. Review on chemistry and bioactivities of secondary metabolites from some medicinal plants and microbes of Bangladesh. Bangladesh Pharm. J. 17, 63-79.

Rashid, R.B., Towsif, F.N., Bushra, F.A. and Tahia, F. 2016. Antioxidant, membrane stabilizing and cytotoxic activities of Cissus adnata (Roxb.). Dhaka Univ. J. Pharm. Sci.15, 69-71.

Salehi, B., Kumar, N.V.A., Sener, B., Sharifi-Rad, M., et al., 2018. Medicinal plants used in the treatment of Human Immunodeficiency Virus. Int. J. Mol. Sci. 19, 1459-1519.

Samsam, S.H. and Moatar, F. 1991. Natural Medicines and Plants. Mashal Publications Tehran pp, 123-130. 
Shinde, U.A., Phadke, A.S., Nair, A.M., Mungantiwar, A.A., Dikshit, V.J. and Saraf, M.N. 1999. Membrane stabilizing activity-a possible mechanism of action for the anti-inflammatory activity of Cedrus deodara wood oil. Fitoterapia 70, 251-257.

Shoba, F.G. and Thomas, M. 2001. Study of anti-diarrhoeal activity of four medicinal plants in castor oil-induced diarrhea. J. Ethnopharmacol. 76, 73-76.
Singh, V.K. and Ali, Z. A. 1998. Herbal Drugs of Himalaya (Medicinal Plants of Garhwal and Kumaon Regions of India). Today and Tomorrow's Printers, India.

VanWagenen, B.C., Larsen, R., Cardellina, J.H., Ran dazzo, D., Lidert, Z.C. and Swithenbank, C. 1993. Ulosantoin, a potent insecticide from the sponge Ulosa ruetzleri. J. Org. Chem. 58, 335-337.

Yuan, H., Ma, Q., Ye, Li. and Piao, G. 2016. The traditional medicine and modern medicine from natural products. Molecules, 21, 559-577. 